\title{
Hostili praedo ditetur lingua latina: Conceptual Narratives of Translation in the Latin Middle Ages
}

\author{
Réka Forrai*
}

Captivas ideo gentiles adveho nugas, Laetor captivis victor ego spoliis. Dives captivos habeat Pregnaria servos Laetetur Grais Cambio mancipiis. Burgulii victae nunc captivantur Athenae, Barbara nunc servit Graecia Burgulio.

Hostili praedo ditetur lingua latina, Graecus et Hebreus serviat edomitus. In nullis nobis desit doctrina legendi, Lectio sit nobis et liber omne quod est. ${ }^{1}$

This article is an experiment: it attempts to look at medieval Latin translation practices through the lenses of a modern sociological theory of narrative. It argues that topoi found in translation prefaces are key elements of narratives that explain why the act of translation is necessary at all. The article identifies three such narratives, and elaborates in particular on one of them, which describes translation with the help of bellic metaphors.

Keywords: narrative; translation; topos; Latin; conflict

\section{Introduction}

On 25th March 876, a small booklet arrived at the court of Emperor Charles the Bald from Rome. It was sent by the pontifical court's librarian, Anastasius, and, as the accompanying letter stated, it consisted of a translation of a Greek text that was supposed to support the emperor in his fight against his enemies. Concerned that the emperor had many opponents, the librarian (and his pontiff, John VIII) had sent the document as an offer to help, something that would facilitate God's aid in the emperor's conflicts:

* Correspondence details: Réka Forrai, Centre for Medieval Literature, University of Southern Denmark, Campusvej 55, DK-5230 Odense M, Denmark; email: forrai@sdu.dk.

1 "I bring here the captive pagan trifles; / I, the victor, rejoice in my captive spoils. / Let the rich Pregnaria have captive servants; / Let the Cambio rejoice in Greek slaves. / Captive Athens is now being captured at Bourgueil, / Barbaric Greece now serves Bourgueil / Let the Latin tongue be enriched by enemy booty; / Let the vanquished Greek and Hebrew serve. / Let us not miss reading's lesson in any (of them); / Let everything that is, be book and text for us.« Baudri of Bourgueil, Poem 238: Ad dominam Constantiam, lines 125-132. Baudri de Bourgueil, Oeuvres, ed. Abraham, 337-342. Translation from Bond, Loving Subject, 171-181. 
Quia vero imperium vestrum tanti fraudare agonistae notitia renui, vobis quoque id ipsum opportune mittere procuravi, quatinus vestra magnitudo cum ceterorum super arenam multiplicatorum intercessionibus amicorum Dei et istius quoque preces apud Deum obtinere satagat, ut perfrui mereatur eorum suffragio. ${ }^{2}$

The text in question was the Passio of Saint Demetrius of Thessaloniki, a so-called warrior saint, who, according to the passion, had successfully intervened with his prayers in favour of a young Christian warrior, Nestor, in his combat with a pagan gladiator. The text was originally written in Greek and translated into Latin by Anastasius himself. I have discussed at length elsewhere the parallels between the characters in the text and in the dedicatory context: ${ }^{3}$ Anastasius offered spiritual support from the papacy to the emperor in his wars, just as Saint Demetrius helped the young Christian win his fight with a pagan. This narrative was supposed to remind the emperor that earthly rulership can only be successful with spiritual help, namely the one best provided by the papacy. Through cross referencing the motifs of the warrior, the mediator saint and his enemies between the dedication letter and the translation, Anastasius succeeded in presenting the institution he represented as a mediator interceding in a conflict. It was supposed to remind the dedicatee (the emperor) of the influential position of his ally (the papacy).

This connection between translation and conflict is the one aspect of Greek-Latin translation culture I would like to investigate in this article. In order to clarify this correlation, I will use a contemporary translation theory, that of translation narratives, developed by Mona Baker. This is my second experiment in coupling modern translation theories with premodern translation practices to see if doing so can help us understand the dynamics of translation history better. ${ }^{4}$ While medieval translation theory in its linguistic dimension was extensively studied, ${ }^{5}$ the political, social and religious dimensions of translation history, and the medieval phase in particular, as Douglas Robinson argues, still need to be explored. ${ }^{6}$ One possible reason why these aspects of translation history have been under-studied - at least in the case of the Middle Ages - is that we think there are not enough sources to base such a history on, prefaces by translators, for example, being scarce and frustratingly similar to each other.

2 Anastasius Bibliothecarius, Epistolae, ed. Perels and Laehr, 438-439. It also exists in a slightly different version: "Sed quia imperium vestrum tanti agonistae fraudari notitia novi, vebis quoque id ipsum opportune mittere procuravi, quatinus vestra magnitudo cum intercessionibus sanctorum et amicorum Dei istius quoque prece apud Deum obtinere gratiam valeat et perfrui mereatur gloria sempiterna. Rex regum et dominus dominantium regnum vestrum dextera sua protegat et de temporali ad aeternum transferat regnum. « Brussels, KBR, 08690-08702 (3213), fol. 065v.

3 Forrai, Byzantine saints, 185-202.

4 The first attempt: Forrai, Translation as rewriting. There were several important attempts in recent years to understand medieval translation with the help of modern theories (although mostly applied to the case of vernacular translations): Campbell and Mills, Rethinking Medieval Translation; Long, Medieval literature; Campbell, Politics; and Warren, Modern theoretical approaches.

5 See the classics of Chiesa, Ad verbum, and Copeland, Rhetoric.

6 "We still need a social history of medieval translation theory in terms, say, of social class, economics, land management, birth order and gender. We still need a political history of medieval translation in terms of shifting church-state relations, and the contested construction of the "individual« or the "self « (as obedient or innovative, as socialized or isolated) in the confluence of those relations; or in terms of conquest and empire, both within and at the borders of "Europe" or "the West", and the geopolitical consolidation of those entities through military conflict with Islam.« Robinson, What is Translation?, 16-17. 
I would argue that we also make our task harder by the way we look at translation prefaces and similar material. When it comes to medieval Latin literature, we are still under the spell of Curtius and the emphasis he placed on topoi as constitutive blocks of medieval Latin literature. It is only a slight exaggeration to say that for him the whole of medieval Latinity is one stockroom of topoi, which has spread from its original environment, ancient rhetoric, and quickly permeated all forms of literature. Curtius insists on using the original Greek word, saying the German and English equivalents are misleading, although he does offer one modern-language equivalent: the French cliché. Viewing medieval Latin literature as a collection of clichés from Antiquity is not fashionable anymore, but seeing these commonplaces as nothing more than banal reiterations of something that was once meaningful but lost its significance entirely, continues. Dedication letters by translators for example, often not being more than a string of such motifs, are dismissed on this ground: the humility topos, the praise of the patron, even the theoretical reflections, the repetitive talk of verbum and sensum methodologies seem to offer no valuable insight into what was really going on in a translator's atelier. The seeming predictability of it disqualifies it as unreliable and thus ill-suited to historical investigation. I would like to argue that this is not the case.

Therefore, I will, in what follows, concentrate not on what is »original « or new in a preface or similar document, but precisely on what is repetitive, what echoes in other places. In arguing for the necessity of their translation, translators usually recur to very similar arguments. These arguments show up in different periods, different geographical areas, and across different disciplines. The constant referencing of certain topoi creates a web of relations between various places and ages. We often hear, for example, of the ignorantia of Latins or the utilitas of the material translated in many of the translators' presentations of their texts. Why were these topoi chosen and not others? What was such a topos meant to evoke in a reader who shared with the translator the same education, the same reference points and what can it tell the modern historian? I will consider topoi as narrative building blocks, motifs that have their place and function in a story the translator in particular, and the target culture in general, wants to tell.

My discussion will be concerned mostly with topoi of a bellic character that treat texts as precious and dangerous. In the preface to the previous Medieval Worlds volume on translation, Pavlína Rychterová quotes Patrick Geary, stating that language in the Middle Ages was a cultural artefact that "could be mobilized (one is tempted to say 'weaponized') for political action". She adds that if we look at languages from this angle, they can help us better understand »the construction of political or cultural loyalties (among others strategies of social inclusion and exclusion), as well as of processes of formation and transformation of collective identities «. ${ }^{7}$ The bellic topoi I discuss expose precisely such strategies to "weaponize« language. In these cases, the meeting of two cultures in the act of translation is not an encounter, but a clash. Looking at translation narratives gives us an opportunity to observe the formation and affirmation of Latin identities in their relationship to other languages and cultures. 


\section{The Narrative Theory of Translation}

Mostly on the basis of the work of two sociologists, Margaret M. Somers and Gloria D. Gibson, ${ }^{8}$ Mona Baker applied narrative theory to studying translations and, in particular, the relationship between translation and conflict. According to Baker, narrative is »the principal and inescapable mode by which we experience the world «. ${ }^{9}$ Her narrative theory is a sociological, not a literary theory, in the sense that it studies how stories constitute and shape realities. It is not concerned with these stories from a narratological point of view. She subscribes to a social view of narratives, one that goes beyond the literary concerns of narratology and observes the stories permeating and shaping our world..$^{10} \mathrm{~A}$ very important aspect of these narratives is that they do not have to be fully articulated. Baker identifies as the smallest unit of such a narrative the metaphor. Narratives can be disrupted, fragmentary, but also interconnected with each other. They are also competing with each other. She argues that the stories we tell ourselves and to which we subscribe exist not necessarily in specific texts but in a whole range of them, on various levels of articulation, from a metaphor to a full-blown story or strings of stories. ${ }^{11}$ Following Somers and Gibson, ${ }^{12}$ she distinguishes between ontological, public, conceptual and meta-narratives.

(a) The ontological narrative is a private narrative, a personal story that explains to others how we see our place in society. It is the narrative of the individual involved in the act of translation. ${ }^{13}$ Anastasius' narrative about himself in the situation above, for example, is one of him as a representative and a messenger - of an institution (papacy), of an idea (a helping God) - one individual in a chain of intermediaries.

(b) The public narrative is designed by larger entities such as institutions, groups of various size and significance. In Baker's theory, media plays a substantial role in shaping this public narrative. ${ }^{14}$ The concepts "media« and "public" are problematic to project back onto the Middle Ages, but I think we can still meaningfully apply this category if we call it »institutional narrative«. The papacy's narrative in our example describes the institution as the supreme mediator of a Christian society: without it, no access to God is possible. Charles can only triumph over his enemies if the papacy intercedes with God on his behalf.

10 "While narratology and linguistics tend to focus on one text at a time, the first mostly on literary texts (and more recently cinema) and the second mostly on oral narratives, narrative theory as outlined here treats narratives - across all genres and modes - as diffuse, amorphous configurations rather than as necessarily discrete, fully articulated local sstoriesr. It is simultaneously able to deal with the individual text and the broader set of narratives in which it is embedded, and it encourages us to look beyond the immediate, local narrative as elaborated in a given text or utterance to assess its contribution to elaborating wider narratives in society. Narrative theory further allows us to piece together and analyse a narrative that is not fully traceable to any specific stretch of text but has to be constructed from a range of sources, including non-verbal material. In so doing, it acknowledges the constructedness of narratives and encourages us to reflect critically on our embeddedness in them." Baker, Translation and Conflict, 4.

11 "a narrative, in the social theory sense, is not necessarily traceable to one specific stretch of text but is more likely to underpin a whole range of texts and discourses without necessarily being fully or explicitly articulated in any one of them. " Baker, Narratives, 5. 
(c) Conceptual narratives are the reflective narratives of disciplines, the stories we tell about our objects of enquiry. In the modern framework, this is the narrative of the scholarship, rather than of the translators involved. ${ }^{15}$ If we take the modern case of historians of Greek-Latin translations, for example, one such dominant narrative told by scholars of the field is the narrative of the inferior quality and quantity of medieval translations as compared to humanist ones. However, because in the premodern period there is no separate field of translation studies, reflection on the discipline is done by the same people who practice the discipline. Thus, the conceptual narratives of translation are to be looked for not in works by translation theorists, but in the affirmations of translators, patrons and readers of translations. Later in this article I will be concerned mostly with this subcategory. It is a disciplinary narrative, the way practitioners and theorists of translation (which in the Middle Ages are mostly one and the same person) talk about their craft. Anastasius, in the case study above for example, conceptualizes the role of his translation as one of mediation, but, interestingly, not between Greek and Latin culture, but between humans and God. I will discuss below some of the major conceptual frames medieval translators offer for their readers about the social role of translation.

(d) Finally, master or meta-narratives are grand narratives that embed influential concepts widely and deeply in all strata of society. Again, the role of mass media in the modern framework makes it possible to talk about narratives permeating all corners of society, while the popularity of their medieval counterparts was limited by the extent of literacy. ${ }^{16} \mathrm{~A}$ medieval example of such a meta-narrative would be, for example, Romanitas, a much-contested cultural-political identity marker that was claimed both by Byzantine and Western European heirs of the Roman Empire. Strongly connected to this meta-narrative is that of translatio imperii et studii - the answers constructed for the question of who the real heirs of the Greeks and Romans were, or how transfer of power and knowledge occurred over the ages.

These narratives are deeply interconnected, being nested in each other like Russian dolls. In my opening example one could see how the personal narrative of Anastasius as an intermediary relies heavily on the public, or institutional narrative of the papacy itself as an intermediary, and the disciplinary narrative of translated texts as intermediaries between earthly and heavenly matters as well as weapons to be used against enemies. One of the implications of this interconnectedness is that it makes visible the social forces that govern a particular translator's choices in terms of texts, methods, patrons and so on.

This narrative theory of translation brings conflict to the centre of discussions about translation. ${ }^{17}$ Baker unpacks her theory about conflict and translation narratives starting from the conceptual narrative. According to her, in contemporary translation studies the prevalent narrative is that of the translator as a mediator, described as a positive figure making dialogue between cultures possible. She draws attention to the use of metaphors in narratives: many, like that of a bridge-builder for example, help to support the image of the

15 Baker, Translation and Conflict, 39-44.

16 Baker, Translation and Conflict, 44-48.

17 Baker, Translation and Conflict; Baker, Narratives, 4-13. See also Robinson's discussion in Robinson, Translation, 161-188. On translation and war more recently, see Franjié, Guerre et traduction, and Samoyault, Traduction et violence. 
translator as someone morally superior. According to her, a re-evaluation of that narrative is needed, and the role and responsibility of translators and interpreters should be critically examined. This is where conflict comes into the picture as a context in which translators' behaviour should be observed. Baker claims that the ever-invoked neutrality of interpreters, for example, is almost never the case: translators and interpreters do not live in a no-man's land, but in their respective collectives, with alliances and loyalties that play a role in the act of interpretation/translation. ${ }^{18}$

Before applying this framework onto some medieval cases, a caveat: as I have already mentioned before, some premodern realities rub against the theory, two in particular. First, in Baker's theory media has a significant role to play in making the public narrative really "public". While we don't have anything like modern media in the Middle Ages, nevertheless, institutions had their ways and tools with which to communicate. In particular, the Church had numerous channels to reach larger crowds. Nevertheless, I will talk about institutional, rather than public narrative to avoid creating the impression that there is no difference between how premodern and modern institutions communicate. Second, in the case of conceptual narratives, Baker's actors are researchers, which is again a category not applicable to the Middle Ages. But this does not mean that there was no reflection on the craft of translation, and that is what Baker is ultimately interested in: the way the discipline reflects

on itself. In the Middle Ages this was done by the translators themselves, or their readers. Because of the lack of the category of researcher it will be slightly more problematic for the Middle Ages to separate the ontological and institutional narratives from conceptual ones, but Baker herself claims that, in fact, the categories of her typology are strongly interrelated, and often overlapping.

\section{Conceptual Narratives of Medieval Translations}

In what follows, I will try to identify some major conceptual narratives - that is to say, narratives that conceptualize translations - of the medieval Greek-Latin translations: why were these translations made at all? Why does one culture look at another with this intention? Baker's definition of conceptual or disciplinary narrative is a broad term, that encompasses all narratives that are "the product of inquiry, the representations elaborated by researchers. ${ }^{19}$ As mentioned above, I will consider conceptual all narrative related by the translators, patrons, or readers of translations that reflects on the nature of the enterprise of translation.

I will look for conceptual narratives in prefaces, letters and other documents, and I will consider topoi and metaphors as fragments of a larger narrative. My examples are from Greek-Latin translation projects, simply because my expertise lies there, but the same principles apply to Hebrew-Latin or Arabic-Latin ones, from which I will present just a few cases. I cannot say whether my theoretical frame is applicable to the case of vernacular translations. My examples are a random selection that is far from being exhaustive. I have tried to pick a few representative samples from projects clustered mainly in the fourth (Jerome and

18 Baker, Narratives, 6.

19 Baker, Translation and Conflict, 39. 
Rufinus), ninth (Anastasius Bibliothecarius and John Scottus Eriugena), eleventh (Constantinus Africanus, Alfanus of Salerno) and twelfth (Burgundio of Pisa and Moses of Bergamo) centuries. Where available, I try to complement the testimony of translators with similar reflections by readers, commissioners, patrons or institutions. These centuries are singled out because there is an intensification of translation activities as compared to other periods. While the long durée I have chosen is not intended to imply that narrative strategies were overwhelmingly unified over the centuries, it will nevertheless show that there is a continuous preoccupation with the same themes.

There are (possibly) many conceptual narratives about the act of translation. In the present paper I distinguish between three main such narratives: the poverty narrative, the utility narrative and, lastly, the bellic narrative. This list is an open list. Based on my readings, these three narratives were the dominant narratives, but that does not exclude the existence of others (e.g. translation as therapy for grief, translation triggered by a random discovery, etc.).

Because all these narrative elements repeatedly show up in translators' prologues, they are often called topoi. By referring to them instead as narrative units, no matter how fragmentary, I want to draw attention to their topicality as a meaningful, rather than an empty property. They are empty only in the sense that no particular effort was made to construct a novel story, a unique narrative fitting only that particular instance of translation. But I argue that by reaching for a well-known narrative, the translators intended their endeavour to be considered in that context, connected to larger narratives.

\section{a. The Poverty Narrative}

The poverty narrative claims that Latin culture, as compared to Greek or Arabic, is impoverished, and translation is one way to remedy this. Translation is described in economic terms, where translation is an act of enrichment, an undoubtedly positive undertaking. The Latin terms describing this state of affairs are inopia, paupertas, penuria (Latinorum). The eleventh-century translator Alphanus (archbishop of Salerno from 1058), in his preface to his translation of the fourth-century thinker Nemesius of Emesa's De natura hominis, refers to the dire situation of penuria: "Et precipue ab his quos mater educavit Graecia, Latinorum cogente penuria. ${ }^{20}$ One argument for translating Greek texts was that Latin lacked books with similar content. Constantine the African, a contemporary and fellow-translator of Alphanus, albeit from Arabic into Latin, said the following about his own translation of the Liber urinae of the physician Isaac Israeli: "In Latinis quidem libris nullum auctorum invenire potui qui de urinis certam et autenticam cognitionem dederit. $\aleph^{21}$ Burgundio of Pisa in the next century complains about the lack of Chrysostom commentaries available to Latins, which motivated him to begin his translation project:

Tum quia eiusdem sancti patris Johannis Chrysostomi commentationem super evangelium sancti Matthaei evangelistae iam pridem beatae memoriae tertio Eugenio papa integre translatam tradideram: tum quia huius Iohannis evangelistae expositionis penuria apud Latinos maxima erat. ${ }^{22}$ 
Oftentimes, however, it is not the poverty of the Latins but the richness of the Greeks that is emphasized: "ad purissimos copiosissimosque Graium latices recurrere«, writes the ninth-century Carolingian theologian John Scottus Eriugena in his preface to his translation of the pseudo-Dionysian corpus.

Sometimes, instead of poverty the term ignorantia and its cognates were featured. This is a very similar narrative that offers translation as a remedy to all kinds of ignorance, personal or collective, concrete or general. ${ }^{23}$ Poverty of one's own culture in general, ignorance of a particular subject matter or lack of material in a very concrete sense are the main shortcomings to which this solution is offered. In this narrative, the target culture, Latin, is seen as inferior to that of the source culture, whether Greek or Arabic, and the translator's ambition is to remedy this deficiency. ${ }^{24}$

\section{b. The Utility Narrative}

The utility narrative argues that translation is a pragmatic act of selection: filtering other cultures through the sieve of use. The Latin terms used are utilitas and proficio and their cognates. It is probably the most widespread of the narratives I discuss, and it can be found from Late Antiquity all the way to the High Middle Ages in many translators' prefaces. Rufinus dedicated his translation of Origen's Commentary on the Epistle of Paul to the Romans to his friend Heraclius around 405. He describes his aim with the help of the dichotomy of "pleasing" as opposed to "useful «, aiming for the latter: "nobis enim propositum est non plausum legentium, sed fructum proficientium quaerere. ${ }^{25}$

In his translation of the Life of John the Almsgiver, dedicated to Pope Nicholas I, Anastasius Bibliothecarius uses the term utilitas, referring to the profit of his readers: »dum tantum intentio mea illo tenderet, ex quo utilitas nasceretur legentibus. ${ }^{26}$ This narrative is very much audience-oriented, whether they be individual readers or greater entities. An example of a larger entity is the kingdom of Frederick II referred to in the following passage of Burgundio of Pisa, in his dedication to the emperor of the Latin version of the above-mentioned De natura hominis by Nemesius of Emessa (which Burgundio believed to be by Gregory of Nyssa):

23 See, for example, Anastasius Bibliothecarius' remark to a certain Ursus, the dedicatee, about the Life of Basil the Great: »vita tamen illius quam sit ammirabilis hactenus ignoravit. « Anastasius Bibliothecarius, Epistolae, ed. Perels and Laehr, 399.

24 In ancient Rome there existed a narrative of linguistic poverty in which Latin was seen as poor in relation to Greek in its ability to express complex human thoughts. Cicero, Lucretius and Quintilian are all known to have struggled with the problem of the expressiveness of Latin and the need to create a new vocabulary, especially for philosophical terminology. Cf. Cicero De natura deorum, 1, 8 (»Graecis ne verborum quidem copia vinceremur«) and De finibus 3, 5 ("Nos non modo non vinci a Graecis verborum copia sed esse in ea etiam superiores"); Lucretius 1, 139 ("egestas linguae«) and I, 832; III, 260 ("patrii sermoni egestas«). See also the discussion in Quintilian 12, 10, 27-39. Jerome also occasionally blamed "propter paupertatem linguae«, Commentary on Ephesians 1.1.4 and Commentary on Isaiah 11.40.12. See Fögen, Patrii sermonis egestas, and Farrell, Latin Language, 28-51.

25 Rufinus Tyrannius, Opera, ed. Simonetti, 277. This echoes Horace's double goal of poetry: dulce and utile (Ars Poetica 343).

26 Further examples from Anastasius: "quatenus tantus vir non tantum sermone Graeco, verum etiam Latino eloquio pollentibus utilitati esset et commodo«; »ex quo utilitas nasceretur legentibus«. Anastasius Bibliothecarius, Epistolae, ed. Perels and Laehr, 396. 
Quae omnia si vestro interventu vestris temporibus in lucem Latinis redacta fuerint, immensam gloriam et aeternum nomen vestra majestas consequetur, et vestra res publica utilitatem maximam adipiscetur. ${ }^{27}$

Moses of Bergamo, another Italian translator of the twelfth century active in Constantinople, refers to the utilitas narrative as his main motivation in a work of compilation-translation: "cum presertim grecas litteras propter id potissimum didicisse me sim sepe testatus, ut ex eis in nostras siquid utile reprerirem quod nobis minus ante fuisset debita devotione transverterem. $\ll^{28}$

This narrative is also echoed in the appreciative comments of patrons. Aimery of Limoges, patriarch of Antioch, wrote in a letter acknowledging the De haeresibus of Hugo Etherianus, another twelfth-century Pisan translator:

Tria sunt denique, pro quibus vestram postulatum accedimus dilectionem, quasi dederitis operam qualiter habeamus et toti Latinitati proficuum, et hoc ipsum vobis erit in praeconium vestrae laudis monimentum aere perennius. ${ }^{29}$

The popularity of this narrative does not mean that utilitas is just a convenient filler word. The utility narrative tells the story of translation as a significant enterprise: the text was not translated to delight, nor was the act of translation a pastime, but an activity strongly anchored in contemporary needs, be they educational or pastoral. The translator's guiding principle lay outside his own literary interests, following the needs and tastes of his audience. The selection of translation material was governed by the conjecture of its possible use in the target culture.

\section{c. The Bellic Narrative}

The topo $i$ of this narrative are all military metaphors. This narrative maintains that translation is the necessary corollary of conflict: texts can and should be taken hostage, and can be used as weapons to successfully fight with the enemy, as I have already shown in the opening example of this paper. ${ }^{30}$

One of the most well-known prefaces of Jerome about his biblical translations is the socalled helmeted preface to the Book of Kings. Here, aware of how difficult and sensitive a subject the question of biblical canon is, he marches his arguments in a helmeted prologue (galeatus), and he closes his dedication with a request to Paula and Eustochium to defend him with the shield of their prayers (orationum vestrarum clypeos).$^{31}$ His military imagery is mostly defensive, but there are a series of popular metaphors in other prologues which are more aggressive, namely translation as loot (spolia) or as a hostage (capta), and translation as a weapon (arma). As they originate from different places, and have slightly different implications, I discuss the spolia/capta and arma metaphors separately.

\footnotetext{
27 Prologus Burgundionis, ed. Durand and Martène, 828-829.

28 Haskins, Studies, 201-202.

29 PL 202, 231-232.

30 On aspects of aggression and translation in the Middle Ages, see Mártinez-Gázquez, Lenguaje de la violencia; Mártinez-Gázquez, Attitude; Pym, Twelfth-century Toledo; and Wheatley, Concepts and models.

31 Vulgate, ed. Weber and Gryson, 364-366.
} 


\section{Spolia/capta}

These two metaphors originate in two biblical passages from the Old Testament:

Si egressus fueris ad pugnam contra inimicos tuos, et tradiderit eos Dominus Deus tuus in manu tua, captivosque duxeris, et videris in numero captivorum mulierem pulchram, et adamaveris eam, voluerisque habere uxorem, introduces eam in domum tuam: quae radet caesariem, et circumcidet ungues, et deponet vestem, in qua capta est: sedensque in domo tua, flebit patrem et matrem suam uno mense: et postea intrabis ad eam, dormiesque cum illa, et erit uxor tua. ${ }^{32}$

And:

Daboque gratiam populo huic coram Aegyptiis: et cum egrediemini, non exibitis vacui: sed postulabit mulier a vicina sua et ab hospita sua, vasa argentea et aurea ac vestes: ponetisque eas super filios et filias vestras, et spoliabitis Aegyptum. ${ }^{33}$

The various interpretations of these two passages have been studied in detail by Georges Foillet; I will focus here only on some of the examples relevant to the present context. Captivity and booty are metaphors used in conceptual narratives for problematic cases where the source culture is considered an enemy, or at least dangerous in some respects. The metaphors of the captives and the Egyptians were used not only narrowly for cases of translation, but for cultural transfer in general. The ubiquity of these metaphors makes us realize that translation narratives are often nestled into bigger narratives, that they cannot be studied in isolation from their larger social context. Interlingual transfers are just a subplot of this narrative, where the general frame is the exploitation of secular or pagan learning to the benefit of Christian culture. The woman or the gold and silver is either pagan knowledge in general, or secular philosophy, or Greek in particular, referred to as disciplina, sapientia, philosophia. In some examples the details are further specified: the gold of the Egyptians signifies sapientia, while their silver stands for scientia. The first to interpret these passages in the sense of cultural appropriation was Origen. ${ }^{34}$ In the Latin world, the imagery was used by both of the two foremost translators of Christian Late Antiquity: Jerome and Rufinus. In their own way, they both struggled to reconcile their pagan education with their Christian vocation, and the metaphors helped them in this. Jerome used the metaphor of the captive woman both for pagan-Christian cultural transfer in general and translation in particular (in this case, Greek-Latin, but also for Hebrew-Latin):

si autem adamaueris captiuam mulierem, id est sapientiam saecularem, et eius pulchritudine captus fueris, decalua eam et inlecebras crinium atque ornamenta verborum cum emortuis unguibus seca. ${ }^{35}$ 
Secular learning has to be made ugly to be of use for the Christians. Its beauty was perceived as something threatening. In Jerome's understanding essential content can and should be separated from its form. This intervention is described in harsh military terms.

In his letter 57 to Pammachius, he describes the translation efforts of Hilary the Confessor with the imagery of the captive translated and the victor translator, who again is interested only in the meaning (sensus) of the captive, and not the linguistic beauty of the text.

Sufficit in praesenti nominasse Hilarium Confessorem, qui Homilias in Iob, et in Psalmos tractatus plurimos in Latinum vertit e Graeco, nec assedit litterae dormitanti, et putida rusticorum interpretatione se torsit: sed quasi captivos sensus in suam linguam, victoris iure transposuit. ${ }^{36}$

Spolia and its synonym praeda occur in Rufinus' preface to his translation of the Clementine recognitions. The passage describes translation as a great effort, the implication being that the original demonstrated some resistance or at least posed some difficulties.

predamque, ut opinor, non parvam, Graecorum bibliothecis direptam. [...] Peregrinas ergo merces multo in patriam sudore transvehimus; et nescio quam gratus me civium vultus accipiat magna sibi Greciae spolia deferentem et occultos sapientiae thesauros nostrae linguae clave reserantem. ${ }^{37}$

The imagery is a favourite of Augustine as well. He goes so far as to claim that those who created these values - in this case, Platonic philosophers - are in fact unjust owners of them, and real ownership belongs to Christian Latin culture. The biblical image of spoiling the Egyptians encourages Christians to remedy this unjustness:

Philosophi autem qui vocantur, si qua forte vera et fidei nostrae accomodata dixerunt, maxime Platonici, non solum formidanda non sunt, sed ab eis etiam tamquam ab iniustis possessoribus in usum nostrum vindicanda. Sicut enim Aegyptii non tantum idola habebant et onera gravia, quae populus Israhel detestaretur et fugeret, sed etiam vasa et ornamenta de auro et argento et vestem, quae ille populus exiens de Aegypto sibi potius tamquam ad usum meliorem clanculo vindicavit non auctoritate propria sed praecepto Dei. ${ }^{38}$

Both the "victoris iure " of Jerome, from the passage above, and the "praecepto Dei« of Augustine claim a kind of legal ownership, they present the transfer from the other language, or the other culture's learning not as a possibility, but as a right of Christianity.

The motifs re-emerge again in another great period for translation projects, the ninth century. Anastasius' contemporary and fellow-translator John Scottus Eriugena uses the biblical passage of the spoiling of the Egyptians to reply to his imaginary critics who blame him for his use of philosophical reasoning (by which they mean his use of Neoplatonic, and thus Greek and pagan, ideas). Looting by God's command makes cultural transfer irreprehensible.

36 Jerome, De optimo genere interpretandi, ed. Bartelink, 14.

37 Rehm, Pseudoklementinen 2, 3-4.

38 Augustine, De doctrina christiana, 2.40.60-42.63; Folliet, »Spoliatio Aegyptiorum«, 11-14. 
Et si quis nobis in culpam reputaverit, quod philosophicis ratiocinationibus usi sumus, videat populum Dei Aegypto fugientem, ejusque divino consilio admonitum spolia ferentem, ipsisque spoliis irreprehensibiliter utentem..$^{39}$

Just as in Late Antiquity, this narrative is popular both with translators and intellectuals who are not directly engaged in intralingual transfers. Another ninth-century thinker, Rhabanus Maurus, for example, prefers the metaphor of the captive woman, dwelling on the details of her transformation: the nails have to be cut with »ferro acutissimo«. He even uses the word "convertere«, a term used for the act of translation, for his reading of pagan literature.

Poemata autem et libros gentilium si velimus propter florem eloquentiae legere, typus mulieris captivae tenedus est, quam Deuteronium describit. [...] Itaque et nos hoc facere solemus, hoc que facere debemus, quando poetas gentiles legimus, quando in manus nostras libri veniunt sapientiae saecularis, si quid in eis utile reprerimus, ad nostrum dogma convertimus; si quid vero superfluum de idolis, de amore, de cura saecularium rerum, haec radamus, his calvitium inducamus, haec in unguium more ferro acutissimo desecemus. ${ }^{40}$

In the twelfth century we find the reference to the treasure of the Egyptians also in legal and educational materials, handbooks, textbooks and reference works such as the Glossa ordinaria ${ }^{41}$ and the Decretum Gratiani. ${ }^{42}$ Pope Gregory IX, in his letter to the masters of theology at the Paris university from 1228, also refers to both biblical passages when admonishing the teachers. The metaphors are offered as hermeneutical tools to problematic texts. The first one, the Egyptian spoils, justifies the act of cultural transfer, while the second one, about the captive women, offers a method for how to approach such materials. ${ }^{43}$

39 De divisone naturae 3, 35 (PL 122; 724a); Folliet, »Spoliatio Aegyptiorum«, 23.

40 Rhabanus Maurus, De institutiones clericorum, ed. Knoepfer, 224-240; Folliet, »Spoliatio Aegyptiorum«, 21.

41 "Per hoc autem quod filii Israel Aegyptios talibus spoliauerunt, significatur quod quaecumque sunt in libris Gentilium, accomodata fidei nostrae siue moribus, ad eorum declarationem, cuiusmodi sunt scientiae reales, siue ad defensionem eorum, cuiusmodi sunt scientiae sermocinales, quae docent modum loquendi, arguendi et respondendi, ab eis, tamquam ab iniustis possesoribus, sunt accipienda." Glossa ordinaria, Libri exodi, 11.2, Postilla; Folliet, »Spoliatio Aegyptiorum«, 28.

42 "Legitur etiam, quod praecepit Dominus filiis Israel, ut spoliarent Egiptios auro et argento, moraliter instruens, ut sive aurum sapientiae, sive argentum eloquentiae apud poetas inveniremus, in usum salutiferae eruditionis vertamus.« Decretum Gratiani, ed. Friedberg and Richter 1, col. 137; Folliet, "Spoliatio Aegyptiorum«, 31.

43 »Magistris in theologia Parisius regentibus. Ab Egyptiis argentea vasa et aurea sic accipienda sunt mutuo, quod spoliatis eisdem ditentur Ebrei, non ut iidem in servitutem illorum quasi ad participium pretii venundati redigantur, quoniam et si doctrina celestis eloquii de sapientia et eloquentia philosophici dogmatis quasi mutuum ad sui ornatum assumat, interdum ei tamen deservire non debet nec intellectus ipsius ad illius intellectum ullatenus inclinari. Puella etiam de hostibus capta, que pilis rasis et ungulis circumcisis viro Israelitico jungitur, dominari non debet eidem, set obsequi potius ut subjecta. Et quidem theologicus intellectus quasi viri habet preesse cuilibet facultati, et quasi spiritus in carnem dominium exercere, ac eam in viam dirigere rectitudinis ne aberret." $C h a r t u$ larius Universitatis Parisiensis, ed. Denifle 1, 114; Folliet, »Spoliatio Aegyptiorum«, 40. 
The metaphor of the beautiful captive is also, in fact, a strikingly precise description of word-for-word translation: a text stripped of all her original embellishments, naked and taken out of her original context against her will, placed in a new context, mourning her losses. Scholars have long noticed that while translators who adhere to the principles of literal translation so typical for the Middle Ages tend to apply it dutifully on the micro-level of the sentence, they often take great liberties on the macro level of the text, such as removing chunks that are uninteresting or in other ways unwelcome in Latin. The language of such editorial practices - omissis superflua (Rufinus), superflua resecamus (Guarimpotus) - in fact strongly echoes the language of the metaphor of the captive woman (superfluum desecemus, above).

\section{Arma}

Another military metaphor that can be argued to constitute a translation narrative is that of the text as arma (spiritualia). It possibly originates in the following passage from Paul's Second Letter to the Corinthians, where he envisions a kind of spiritual militia that forcefully spreads divine knowledge with spiritual weapons:

In carne enim ambulantes, non secundum carnem militamus. Nam arma militiae nostrae non carnalia sunt, sed potentia Deo ad destructionem munitionum, consilia destruentes, et omnem altitudinem extollentem se adversus scientiam Dei, et in captivitatem redigentes omnem intellectum in obsequium Christi. ${ }^{44}$

While the captiva/spolia metaphor was more often used historically, for cultures past (ancient Greece, ancient Rome, the Jewish culture of the Old Testament), the arma metaphor shows up in the translation narratives of contemporary situations, when referring to rival societies or religions such as the Byzantine Greek Church, various heresies, Judaism or Islam.

Anastasius Bibliothecarius, for example, in his letter to Pope John VIII describes documents as tools that can help fight the enemy "potenter" - in this case, the Greek heretics:

Unde apostolatu vestro decernente non solum illos solos quinquaginta canones ecclesia recipit, sed et omnes eorum, utpote Spiritus sancti tubarum, quin et omnium omnino probabilium Patrum, et sanctorum conciliorum regulas et institutiones admittit, illas duntaxat quae nec rectae fidei, nec probis moribus obviant, sed nec sedis Romanae decretis ad modicum quid resultant, quin potius adversarios, id est haereticos, potenter impugnant.

Isidore Mercator (a pseudonym for one, or possibly several, ninth-century theologians), in his preface to his collection of ecclesiastical legislative texts (part of which is a translation from Greek), draws a parallel between soldiers and theologians, and spears and sentences:

Et sicut militi ex multis armis illa sufficiunt quae ferre congruenter super se praegerit, sic nobis de multis sententiis una aut duae vel quantum tunc temporis necesse fuerit, sufficiunt, quoniam sicut cum uno telo aut duobus inimicum vincimus, sic cum una aut duabus sententiis auctoritate plenis emulum superamus. ${ }^{45}$ 
Peter the Venerable, twelfth-century abbot of Cluny, twice referred to fighting heresies with texts (translated or otherwise). He was not himself a translator, but he was the commissioner of the most ambitious medieval translation project concerning Islam, which included the translation of the Koran itself. These translations had their place in the Christian arsenal as weapons to fight the very people who produced the originals.

Quod si forte haec de qua agitur scriptura aut interpretes non habuerit, aut translata non profuerit, habebit saltem Christianum armarium etiam aduersus hos hostes arma quibus aut se muniat, aut quibus si forte ad certamen uentum fuerit, inimicos confodiat. ${ }^{46}$

Nam licet hoc perditis illis ut aestimo prodesse non possit, responsionem tamen condignam sicut contra alias hereses, ita et contra hanc pestem, Christianum armarium habere deceret. Quam si superfluam quilibet causatus fuerit, quoniam quibus resistere debeant talibus armis muniti non adsunt, nouerit in re publica magni regis quaedam fieri ad tutelam, quaedam fieri ad decorem, quaedam etiam ad utrumque. ${ }^{47}$

Mark of Toledo, one of the early translators of the Koran into Latin, wrote in his prologue in a very similar vein, even using the same word "confundere«: the aim of the translation is to confuse the enemy.

Hic nimirum antistes quem divine scientie litteratura commendat, [...]perscrutabiliter operam dedit et sollicitudinem, ut liber in quo sacrilega continebantur instituta et enormia precepta translates, in noticiam venirent orthodoxorum, ut quos ei non licebat armis impugnare corporalibus, saltem enormibus institutis obviando confunderet. ${ }^{48}$

Humbertus de Romanis, master general of the Dominican order, prepared a document for the 1274 Council of Lyon, suggesting some plans for action to remedy the conflict between Greeks and Latins. In his strategy, the question of languages and translations was meant to play a crucial role. The science of Christ was to be defended with spiritual weapons, whether against Arabs, Jews or Greeks, or other nations. He complained that translators only focused on legal and philosophical material, and did not translate enough from religious writings that could be helpful in this fight (note that he also speaks about the abundance of the Greek books, copia):

46 Peter the Venerable, Liber contra sectam sive haeresim Saracenorum, in Kritzeck, Peter the Venerable, 230.

47 Letter to Bernard of Clairvaux: Peter the Venerable, Epistula ad Bernardum Claraevallis, in Kritzeck, Peter the Venerable, 212; Martínez Gázquez, Attitude, 63. See also Mártinez-Gázquez, Lenguaje de la violencia.

48 Martínez Gázquez, Attitude, 98; D’Alverny and Vajda, Marc de Tolède, 260-261. See also his prologue to the Habentomenti De Unione Dei: "Transtuli siquidem librum Habentomei post librum Mafometi, ut ex utriusque inspectione fideles in Saracenos invehendi exercitamenta sumant ampliora. « D’Alverny and Vajda, Marc de Tolède, 268-269; Martínez Gázquez, Attitude, 99. 
Aliud est copia librorum Graecorum, ut videlicet haberent Latini omnia scripta Graecorum [...]. Cum enim veritas sit pro Latinis, indubitanter invenirentur multa in hujusmodi scriptis, quibus juvarent se Latini contra Graecos, vel quibus se defenderent ab eis, sicut per scripta Veteris Testamenti defendimus nos a Iudaeis, et impugnamus ipsos. Sed heu! curatum est multum de libris philosophicis et legibus habendis ab eis: de his autem, quae ad salutem et ad bonum commune pertinent animarum, non est ita curatum. Etsi enim aliqua de his translata sunt, habemus tam pauca, et ipsa originalia in Graeco non habemus, ex quorum inspectione veritas magis clareret, et fortius possent Graeci impugnari. [...] Et Latini nostri muniunt se assidue armis carnalibus contra se invicem et contra Graecos, et de istis armis spiritualibus non curant, neque contra Saracenos, neque contra Judaeos, neque contra Graecos, et alias nationes extollentes se adversus scientiam Christi. ${ }^{49}$

Roger Bacon in his Opus maius, dedicated to Pope Clement IV and containing all his reform ideas about learning, also saw this added benefit of translating Greek theology: it not only enriches Latin learning; it is a strong help in fighting and convincing the heretical Greeks:

Similiter libri doctorum magnorum, ut beatorum Dionysii, Basilii, Johannis Damasceni et aliorum multorum deficiunt [...] et si libri istorum translati essent, non solum augmentaretur sapientia Latinorum, sed haberet Ecclesia fortia adjutoria contra Graecorum haereses et schismata, quoniam per sanctorum eorum sententias, quibus non possunt contradicere, convincerentur. ${ }^{50}$

This narrative posits a more complex relationship between Latin culture and the cultures it came into contact with. The other narratives are unidirectional: the source culture is seen as passive, but somehow superior, while the target one is active, but inferior. The bellic narrative, however, reveals a more complicated relationship between the two. The translation act is just the first act in an interaction that has as its main aim competition, subjugation, conversion, fuelled by rivalry. It supposes a certain resistance from the source culture, a tension between the two respective linguistic realms, and the hierarchy between them is reversed: the target culture is the more powerful, while the source one is seen as weak. It also becomes bidirectional, in the sense that the spoils taken hostage are often turned against the source culture.

Ancient and medieval translators would have agreed with Mona Baker in connecting translation and conflict. They had always viewed and practised their craft following pragmatic and ideological, rather than idealistic principles. The translator, even when he is called mediator, or even when he claims to do intercessio, was expected to be embedded in the political-religious culture of the target society. Interpreters were often criticized, even blamed for the outcomes of conflicts, as manipulators. Translators' patronage was also founded on loyalties that left no space for neutrality. Translation seen as/in conflict thus reveals a lot about the social settings of acts of communication and interpretation. Medieval narratives of such situations are far less naive than the contemporary ones criticized by Mona Baker. Often, the translator was an active participant in the conflict, and translation was seen as a conquest, while the texts produced were seen as spoils or weapons.

49 Humbertus de Romanis, Opus tripartitum 2, 17, ed. Brown, 220-221.

50 Roger Bacon, Opus maius, ed. Bridges 1, 70. 


\section{Conclusions}

In this paper I have tried considering topoi as small narrative units. This article barely sets the parameters of the hypothesis up. There are several avenues where it would be worth pursuing the question of narratives further. Doing so might help us to understand better the application of certain translation methods; the popular narratives might also be useful in understanding less popular narratives; it would also open up possibilities for chronological or geographical investigations (When and where are certain narratives popular, and why? Why do they disappear and reappear?).

But what I have initially attempted to do here is to provide a classification and collection of some major conceptual translation narratives, and to see if these units can give a fuller picture of why a society starts to produce translations. I have assumed that use of such topoi by medieval writers was intentional and done with the intention of connecting with the greater context of larger narratives, earlier and contemporary ideologies. The three narratives I have identified here are three narratives of Christian Latin culture as it sought to define itself in relationship to other cultures: seeing their languages and cultures as impoverished, focusing on the useful rather than the pleasing elements, and framing it all as part of a conquest.

Most of the topoi discussed here have their roots in classical Roman literature. Horace thought the struggle for cultural dominance was won by Greece; ${ }^{51}$ Cicero encouraged the Romans "to snatch the glory of its genre [referring to philosophy] from the already ailing Greece and to transmit it to this city «..$^{2}$ Medieval translators heard these ancient echoes, and also wanted their readers to hear them, as part of the grand narrative of Latin language and culture about itself as a hungry linguistic empire that devoured its neighbours and rivals. Baudri of Borgeuil's vision quoted at the beginning of this paper is that of a Latin Christianity that absorbed and purified all alien wisdoms, past and present.

\section{Acknowledgements}

This work was supported by the Danish National Research Grant Foundation DNRF Grant 102ID. 


\section{References}

Abbreviations

$\mathrm{CCSL}=$ Corpus Christianorum Series Latina

$\mathrm{KBR}=$ Royal Library of Belgium

MGH = Monumenta Germaniae Historica

PL = Patrologiae Cursus Completus, Series Latina, ed. Jacques-Paul Migne (Paris, 1844-1890).

\section{Manuscripts}

Brussels, KBR, 08690-08702 (3213)

\section{Primary sources}

Anastasius Bibliothecarius, Epistolae sive praefationes, ed. Ernst Perels and Gerhard Laehr, MGH, Epistolae 7, Karolini aevi 5 (Berlin, 1928).

Baudri de Bourgueil, Oeuvres Poétiques, ed. Phyllis Abraham (Paris, 1926).

Bond, Gerald A., The Loving Subject, Desire, Eloquence, and Power in Romanesque France (Philadelphia, 1995).

Burkhard, Carolus, Nemesii Episcopi premnon physicon a N: Alfano archiepiscopo Salerni in Latinum translates (Leipzig, 1917).

Chartularius Universitatis Parisiensis, ed. Heinrich Denifle (Paris, 1889).

D’Alverny, Marie-Thérèse and Georges Vajda, Marc de Tolède, traducteur d'Ibn Tumart, Al-Andalus 16 (1951) 99-140, 259-307; 17 (1952) 1-56.

Decretum Gratiani, ed. Emil Friedberg and Emil Ludwig Richter (Leipzig, 1879).

Hischius, Paul, Decretales Pseudo-Isidorianae et Capitula Angilramni (Leipzig, 1863).

Humberti de Romanis, Opus tripartitum, ed. Edward Brown, Appendix ad fasciculum rerum expetendarum et fugiendarum (London, 1690) 185-229.

Jerome, De optimo genere interpretandi, ed. Gerhard J. M. Bartelink (Leiden, 1980).

Jerome, Epistulae, ed. Isidorus Hildberg (New York, 1970).

Peter the Venerable, Epistula ad Bernardum Claraevallis, in: James Krizteck, Peter the Venerable and Islam (Princeton, 1964) 212-214.

Peter the Venerable, Liber contra sectam sive haeresim Saracenorum, in: James Krizteck, Peter the Venerable and Islam (Princeton, 1964) 220-292.

Prologus Burgundionis, ed. Ursin Durand and Edmund Martène, Veterum scriptorum et monumentorum historicorum, dogmaticorum, moralium, amplissima collection 1 (1724).

Rehm, Bernhard (ed.), Die Pseudoklementinen. Vol 2: Rekognitionen in Rufins Übersetzung (Berlin, 1965).

Rhabanus Maurus, De institutione clericorum, ed. Aloisius Knoepfer (Munich, 1900).

Roger Bacon, Opus maius, ed. John Henry Bridges (Oxford, 1897).

Rufinus Tyrannius, Opera, ed. Manlio Simonetti, CCSL 20 (Turnhout, 1961).

Vulgate, Biblia Sacra iuxta vulgatam versionem, ed. Robert Weber and Roger Gryson (fifth edition) (Stuttgart, 2007). 


\section{Secondary literature}

Baker, Mona, Narratives in and of translation, SKASE Journal of Translation and Interpretation 1 (2005) 4-13.

Baker, Mona, Translation and Conflict: A Narrative Account (New York, 2006).

Campbell, Emma, The politics of medieval European translation, in: Jonathan Evans and Fruela Fernandez (eds.), The Routledge Handbook of Translation and Politics (London, 2018) 410-423.

Campbell, Emma and Robert Mills (eds.), Rethinking Medieval Translation: Ethics, Politics, Theory (Cambridge, 2012).

Chiesa, Paolo, Ad verbum o ad sensum? Modelli e conscienza metodologica della traduzione tra tarda antichità e alto medioevo, Medioevo e Rinascimento 1 (1987) 1-51.

Copeland, Rita, Rhetoric, Hermeneutics and Translation in the Middle Ages (Cambridge, 1991).

Farrell, Joseph, Latin Language and Latin Culture from Ancient to Modern Times (Cambridge, 2001).

Fögen, Thorsten, Patrii sermoni egestas: Einstellungen lateinischer Autoren zu ihrer Muttersprache (Munich, 2000).

Folliet, Georges, La "spoliatio Aegyptiorum« (Exode 3:21-23; 11: 2-3; 12:35-36): Les interprétations de cette image chez les pères et autres écrivains ecclésiastiques, Traditio 57 (2002) 1-48.

Forrai, Réka, Byzantine saints for Frankish warriors: Anastasius Bibliothecarius' Latin version of the Passion of Saint Demetrius of Thessaloniki, in: Sulamith Brodbreck, JeanMarie Martin, Annick Peters-Custot and Vivien Prigent (eds.), L'héritage Byzantin En Italie (VIIIe-XIIe siècle) 3: Décor Monumental, Objets, Tradition Textuelle (Rome, 2015) 185-202.

Forrai, Réka, Translation as rewriting: A modern theory for a premodern practice, Renaessanceforum 14 (2018) 25-49.

Franjié, Lynne, Guerre et traduction: Représenter et traduire la guerre (Paris, 2016).

Haskins, Charles Homer, Studies in the History of Mediaeval Science (Cambridge, 1924).

Long, Lynne, Medieval literature through the lens of translation theory: Bridging the interpretive gap, Translation Studies 3 (2010) 61-77.

Mártinez-Gázquez, José, The Attitude of the Medieval Translators Towards the Arabic Sciences (Florence, 2016).

Mártinez-Gázquez, José, El lenguaje de la violencia en el prológo de la traducción latina del Corán impulsada por Pedro el Venerable, Cahiers d'Études Hispaniques Médiévales 28 (2005) 243-252.

Pym, Anthony, Twelfth-century Toledo and strategies of the literalist Trojan horse, Target 6/1 (1994) 43-66.

Robinson, Douglas, Translation and the Problem of Sway (Amsterdam, 2011).

Robinson, Douglas, What is Translation? Centrifugal Theories, Critical Interventions (Kent, Ohio, 1997).

Rychterová, Pavlína, Instead of an introduction: Medieval Europe translated, Medieval Worlds 11 (2020) 2-16.

Samoyault, Tiphaine, Traduction et violence (Paris, 2020).

Somers, Margaret R. and Gloria D. Gibson, Reclaiming the epistemological "Other«: Narrative and the social constitution of identity, in: Craig Calhoun (ed.), Social Theory and the Politics of Identity (Oxford, 1994) 37-99.

Warren, Michelle, Modern theoretical approaches to medieval translation, in: Jeanette Beer (ed.), A Companion to Medieval Translation (London, 2019) 165-174. 
Wheatley, Edward, Concepts and models of translation in Medieval Europe, in: Harald Kittel, Armin Paul Frank, Norbert Greiner, Theo Hermans, Werner Koller, José Lambert, Fritz Paul (eds.), Übersetzung, Translation, Traduction 2: 1300-1308 (Berlin, 2007). 